\title{
Original article \\ Cycling above rather than below lactate threshold is more effective for nitric oxide release and post-exercise blood pressure reduction in individuals with type- 2 diabetes
}

\author{
Ricardo Yukio Asano \\ Catholic University of Brasília, Brazil \\ Rodrigo Alberto Vieira Browne \\ Federal University of Rio Grande do Norte, Brazil \\ Rafael da Costa Sotero \\ Marcelo Magalhães Sales \\ José Fernando Vila Nova de Moraes \\ Carmen Sílvia Grubert Campbell \\ Herbert Gustavo Simões \\ Catholic University of Brasília, Brazil
}

\begin{abstract}
The purposes of this study were to analyze and compare the effects of exercise performed in different intensities, above and below lactate threshold (LT) on post-exercise blood pressure (BP) and nitric oxide (NO) responses in individuals with type 2 diabetes (T2D). For this, 11 T2D underwent the following sessions: 1) control session; 2) 20-min of moderate cycling (80\% LT); and 3) 20-min of high intensity cycling (120\%LT) on a cycle ergometer. Plasma NO and BP measurements were carried out at rest and at 15 and $45 \mathrm{~min}$ of post-sessions. When compared to rest, only the exercise session performed at $120 \% \mathrm{LT}$ elicited an increase of $\mathrm{NO}$ (from 7.2 to $9.5 \mu \mathrm{M}$, $p<0.05$ ), as well as a decrease in systolic $\mathrm{BP}$ (from $126.6 \pm 7.9$ to $118.7 \pm 3.9 \mathrm{mmHg}, p<0.05$ ) during the post-exercise period. In conclusion, the results suggest that NO release and post-exercise BP decrease are intensity-dependent for individuals with T2D.
\end{abstract}

Keywords: nitric oxide, type-2 diabetes, high intensity exercise

Resumo- "Ciclismo acima do limiar de lactato é mais efetivo que abaixo para liberação de óxido nítrico e redução da pressão arterial pós-exercício em indivíduos com diabetes tipo 2." Os objetivos do presente estudo foram analisar e comparar os efeitos do exercício realizado em diferentes intensidades, acima e abaixo do limiar de lactato (LL), sobre a resposta da pressão arterial (PA) e óxido nítrico (NO) em indivíduos com diabetes tipo 2 (DM2). Para tanto, 11 DM2 foram submetidos às seguintes sessões: 1) sessão controle; 2) 20 min de exercício em cicloergômetro em intensidade moderada (80\%LL); e 3) 20 min de exercício em cicloergômetro em alta intensidade (120\%LL). O NO plasmático e as medidas de PA foram realizadas no repouso, bem como aos 15 e $45 \mathrm{~min}$ do período de recuperação de todas as sessões. Quando comparado ao período de repouso, somente a sessão de exercício realizado a 120\%LL promoveu aumento do $\mathrm{NO}$ (de 7,2 para $9,5 \mu \mathrm{M}, p<0,05)$ e, por conseguinte, uma diminuição na pressão arterial sistólica (de 126,6 $\pm 7,9$ para 118,7 7 3,9 mmHg, $p<0,05$ ) durante o período de recuperação pós-exercício. Em conclusão, os resultados sugerem que a liberação de $\mathrm{NO}$ e a diminuição da PA parecem ser intensidade-dependente para indivíduos com DM2.

Palavras-chaves: óxido nítrico, diabetes tipo 2, exercício de alta intensidade

Resumen - "Ciclismo arriba del umbral de lactato es más efectivo que abajo para la liberación de óxido nítrico y reducción de la presión arterial después del ejercicio en individuos con diabetes tipo 2." Los objetivos del presente estudio fueron examinar y comparar los efectos del ejercicio realizado en diferentes intensidades, arriba y abajo del umbral de lactato (UL), sobre la respuesta de la presión arterial (PA) y el óxido nítrico (NO) en individuos con diabetes tipo 2 (DM2). Por lo tanto, 11 DM2 se sometieron las siguientes sesiones: 1) sesión control; 2) 20 min de ejercicio en cicloergómetro a una intensidad moderada (80\%UL); y 3) 20 min de ejercicio en cicloergómetro a una intensidad alta (120\%UL). El NO plasmático y las mediciones de la PA fueron realizados en reposo y en 15 y 45 min del período de recuperación para todas las sesiones. En comparación con el período de reposo, sólo la sesión de 
ejercicio realizado a $120 \%$ UL promovió aumento de $\mathrm{NO}(7,2$ para $9,5 \mu \mathrm{M}, p<0,05)$ y, por lo tanto, una disminución de

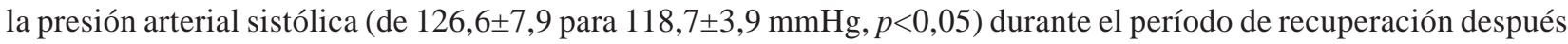
del ejercicio. En conclusión, los resultados sugieren que la liberación de NO y la disminución de PA parece ser intensidad-dependiente para individuos con DM2.

Palabras claves: óxido nítrico, diabetes tipo 2, ejercicio de alta intensidad

\section{Introduction}

Type-2 diabetes (T2D) is among the diseases with higher incidence and prevalence throughout the world (Wild, Roglic, Green, Sicree, \& King, 2004), and is associated mainly with a sedentary lifestyle and inadequate feeding habits (Hu et al., 2001). This pathology is associated to several cardiovascular complications, including endothelial dysfunction and arterial hypertension (Resnick \& Howard, 2002). Endothelial dysfunction results in a lower activity of vasodilator proteins such as those of kallikrein-kinin system, and therefore in a lower bioavailability of endothelial nitric oxide (NO) (Miche et al., 2006).

Physical exercise has been recommended as a nonpharmacological treatment of systemic arterial hypertension (SHA) (Chobanian et al., 2003) and T2D (Colberg et al., 2010), since it elicits a significant post-exercise blood pressure (BP) and glycaemia reduction. The lactate threshold (LT) has been applied on aerobic evaluation and exercise prescription for individuals with T2D (Sales et al., 2012; Morais et al., 2011; Motta et al., 2010), once exercise below LT is considered a safe intensity associated to a low metabolic and cardiovascular stress (Sales et al., 2011; Simões, Moreira, Moffatt, $\&$ Campbell, 2010). On the other hand, the benefits of exercise may be dependent of which intensity it is performed (Bahr \& Sejersted, 1991).

Some studies revealed that a single exercise session can promote a significant BP decrease over minutes or hours after exercise, when compared to pre-exercise values (Sales et al., 2012; Morais et al., 2011; Motta et al., 2010; Simões, Moreira, Moffatt, \& Campbell, 2010). This phenomenon is known as post-exercise hypotension (PEH) and has been suggested to be dependent of NO release, which is a powerful vasodilator (Asano et al., 2012; Santana et al., 2011; Patil, DiCarlo, \& Collins, 1993). However the mechanisms and the relationships between NO release and PEH remain inconclusive (Halliwill, Minson, \& Joyner, 2000; Pescatello, Fargo, Leach, \& Scherzer, 1991), especially for T2D .

On the other hand, previous studies have suggested that, after performing exercise around the LT intensity, individuals with T2D present lower post-exercise BP reduction when compared to their non-diabetic (ND) pairs (Motta et al., 2010; Lima et al., 2008). This could be partially explained by the decreased activity of plasma kallikrein (Motta et al., 2010), as well as a lower NO release in this population (Asano et al., 2012; Stabler, Katherine, Ham, Jelesoff, \& Allen, 2010).

The effects of different exercise intensities on both NO release and PEH in individuals with T2D are still unknown. The present study hypothesized that both NO production and the occurrence of PEH, in individuals with T2D, would be dependent of exercise intensity domain. Thus, exercise performed above LT would elicit a higher NO release and a more significant PEH in individuals in T2D due to a higher metabolic and cardiovascular stress (Moreira, Simões, Hiyane, Campbell, \& Simões, 2007; Simões et al., 2010). Therefore, the aim of the present study was to analyze and compare the effects of different exercise intensities (above and below LT) on post-exercise BP and NO responses for individuals with T2D.

\section{Method}

\section{Sample}

After approval from the ethics committee of the Catholic University of Brasília (n. 167/2011) and signature of the informed consent form, eleven individuals clinically diagnosed with type-2 diabetes, from both sexes, and nonsmokers, were evaluated (Table 1). Though non-insulin dependent, the volunteers were taking oral hypoglycemiants such as sulfonylureas, metformin, metformin+glibenclamide, glimepiride, pioglitazone chloridrate and/or had controlled food intake. Exclusion criteria for participation included detection of any abnormality in the resting electrocardiogram observed by a cardiologist, previous diagnosis of peripheral and autonomic neuropathy, retinopathy, as well as diabetic foot ulcerations, orthopedic complications, or any other problems that could impair the participants' ability to complete all the study procedures. Participants under use of insulin were not included in the studied sample.

\section{Procedures}

Two hours before all experimental sessions the volunteers ingested a standard breakfast with a moderate glycaemic index. The 'breakfast kit' was composed by a $40 \mathrm{~g}$ vanilla flavoured mini-cake (Pullman ${ }^{\circledR}$ ), a $200 \mathrm{ml}$ cup of mango flavoured light juice (Minute Maid Plus ${ }^{\circledR}$ ) and a $30 \mathrm{~g}$ salty biscuit pack (Pit Stop ${ }^{\circledR}$ ). In total, $315 \mathrm{kcal}$ were offered from $51.6 \mathrm{~g}$ of carbohydrate $(66.9 \%), 4.6 \mathrm{~g}$ of protein $(5.8 \%)$ and $9.5 \mathrm{~g}$ of fat $(27.1 \%)$. The glycaemic index of the 'kit' was considered moderate.

The volunteers were instructed to interrupt the use of medicines (time to partially offset the effects of medicaments, and prevent damage to blood glucose and blood pressure of volunteers), to refrain from physical activity and to avoid ingestion of alcoholic beverages and caffeine during the 24 
hours that preceded experimental sessions.

Throughout the study, the volunteers visited the Physical Evaluation and Training Laboratory at the Catholic University of Brasília four times. The first visit consisted of a maximal incremental test on a cycle ergometer in order to determine LT. Afterwards, the subjects underwent to three sessions: exercise at moderate intensity ( $80 \%$ LT); high intensity (120\% LT), and a control session (without exercise). The intensities were classified as moderate (below LT) and intense (above LT) according to previous authors Poole and Richardson (1997), Simões, Denadai, Baldissera, Campbell, and Hill (2005) and Denadai and Caputo (2003). Experimental sessions were performed in a randomized order, with an interval that varied from 72 to 120 hours between experimental sessions.

\section{Incremental exercise test}

Initially, the volunteers remained seated for $20 \mathrm{~min}$ and then a resting electrocardiogram was performed and blood glucose was measured. Afterwards, an incremental test using an electromagnetic cycle ergometer (Lode Excalibur Sport, Netherlands) was initiated. The test started with a 1-minute warm-up at $60 \mathrm{rpm}$ without load, followed by a 15 -watt increment at each 3-minute stage until volitional exhaustion.

During rest before exercise, as well as during the last 10 seconds of each incremental stage, $25 \mu \mathrm{L}$ of blood were collected from earlobe. These blood samples were collected after puncture by using disposable lancets and heparinized capillary tubes (the first drop of blood was discharged to prevent sample contamination). The blood samples were then stored in microtubes (Eppendorf ${ }^{\circledR}$ ) containing $50 \mu \mathrm{L}$ of sodium fluoride $(\mathrm{NaF})$ at $1 \%$ for later analysis of lactate concentrations [Lac] through the electroenzymatic method (Yellow Springs 2700S).

Expired gases were measured during the incremental test through a gas analyzer (Metalyzer 3B, Cortex Biophysik, Germany), which was previously calibrated with a $3 \mathrm{~L}$ syringe (flow calibration) and a mixed pattern of gas containing $4.9 \%$ of $\mathrm{CO}_{2}$ and $17.0 \%$ of $\mathrm{O}_{2}$ (gas calibration). The values of ventilation ( $\mathrm{VE})$, oxygen consumption $\left(\mathrm{VO}_{2}\right)$, and carbon dioxide production $\left(\mathrm{VCO}_{2}\right)$ were registered during the last 20 sec of each 3 min stage. In addition, BP (Microlife ${ }^{\circledR}$ ) and heart rate (HR) (Polar S810, Kempele, Finland) were also measured. $\mathrm{VO}_{2}$ peak was considered as the highest oxygen consumption attained at the exhaustion moment (Howley, Bassett, \& Welch, 1995). Electrocardiograph patterns were registered and accompanied by a cardiologist throughout the whole test.

\section{Lactate threshold determination (LL)}

In order to determine LL, the [Lac] kinetics during the incremental test was analyzed. The exercise intensity (Watts) corresponding to the LL was determined by visual inspection, by considering the exercise intensity in which an over proportional increase of [Lac] was observed (Sales et al., 2011). In addition, whenever necessary the second order polynomial function, which consist of applyind the [Lac] workload ratio versus increase workload to identify the vertices and thus confirm the LL intensity (Simões, Moreira, Moffatt, \& Campbell, 2010).

\section{$120 \%$ LT session (S120)}

The S120 was considered a high intensity exercise session and consisted of $20 \mathrm{~min}$ of aerobic exercise on a cycle ergometer (Lode Excalibur Sport, Netherlands) at a constant load corresponding to $120 \%$ of the LT.

\section{$80 \%$ LT session (S80)}

The S80 session was considered moderate exercise session and consisted of a 20 min cycle ergometer exercise (Lode Excalibur Sport, Netherlands) at a constant load corresponding to $80 \%$ of the LT.

\section{Control session (CON)}

During the CON session, participants remained at rest in a seated position for 20 min without exercise. However, the same data collection procedures were carried out, as described in the S120 and S80 session.

\section{Pre- and post-exercise procedures}

Prior to the S120, S80 and CON sessions, the participants remained seated at rest for blood sampling, as well as for collection of hemodynamic and respiratory variables. The measured variables included BP (BP 3AC1-1, Microlife AG, Widnau, Switzerland), HR (Polar ${ }^{\circledR}$ S810i, Polar Electro Oy Kempele), as well as blood lactate [Lac] and glucose (bGluc) (YSI 2700, YSI Inc, Yellow Springs, OH, USA). The $25 \mu \mathrm{L}$ of blood were collected from ear lobe following the same procedures described in the incremental test section. The pre-exercise measures were done every $5 \mathrm{~min}$ up to $20 \mathrm{~min}$. The BP and HR were measured at the same moments. After performing exercise and $\mathrm{CON}$, the volunteers remained seated for $45 \mathrm{~min}$ in which capillary blood $(25 \mu \mathrm{L})$ and venous blood $(8 \mathrm{ml})$ were collected at the $15^{\text {th }}$ and $45^{\text {th }}$ min of post exercise recovery period.

\section{Venous blood sample collection}

Blood samples $(8 \mathrm{ml})$ were collected for $\mathrm{NO}$ analysis using a hypodermic syringe and deposited in two vacuette ${ }^{\circledR}$ tubes (4 ml) (BD, New Jersey, USA) containing EDTA. The samples were centrifuged at room temperature for $15 \mathrm{~min}$ at $3000 \mathrm{rpm}$. The plasma aliquots were separated in microtubes $\left(\right.$ Eppendorf ${ }^{\circledR}$ ) and immediately stored at $-20^{\circ} \mathrm{C}$. 


\section{Nitric oxide $(\mathrm{NO})$ concentration}

Plasma NO concentration was predicted from plasma nitrite measurements. For this $50 \mu \mathrm{L}$ of phosphate-buffered saline (PBS) were added in the sample's standard curve wells using 96-well plates. Afterwards, $100 \mu \mathrm{L}$ of $\mathrm{NaNO}_{2}$ at $100 \mu \mathrm{M}$, previously diluted in a 1:200 ratio, were added in the first sample's standard curve wells. Later, successive dilutions in a 1:2 ratio in the following wells were performed to determine the nitrite's standard curve. In the sample's wells, $50 \mu \mathrm{L}$ of plasma were added together with $100 \mu \mathrm{L}$ of a mixture containing sulfanilide at $1.0 \%$ in phosphoric acid at $2.5 \%$, and naftiletilenodiamide at $1.0 \%$ in phosphoric acid at $2.5 \%$ in a 1:1 ratio was added. After $10 \mathrm{~min}$ of incubation at room temperature the ELISA reading at $540 \mathrm{~nm}$ was performed. The amount of nitrite from each sample was calculated using the absorbance linear regression equation from the known quantity of nitrite from the $\mathrm{NaNO}_{2}$ solution $(200 \mu \mathrm{M}$ to $0.097 \mu \mathrm{M})$ (Tsikas, 2007).

\section{Statistical analysis}

Normality of data was tested through skewness and kurtosis tests, with all variables presenting values between -1.0 and + 1.0. Analysis of variance (ANOVA) for repeated measures with Bonferroni's post hoc were applied to compare between (S120, S80 and CON) and within (rest, $15 \mathrm{~min}$ post-exercise, and 45 min post-exercise) values of systolic blood pressure, diastolic blood pressure, mean blood pressure and nitrite (as NO measure). Pearson correlation was applied between NO results and PEH. Data are expressed in mean \pm standard deviation. The level of significance adopted was $5 \%(p<0.05)$ and all procedures were performed using the Statistical Package for the Social Sciences (SPSS) v.15.0 for windows.

\section{Results}

Table 1 presents the main characteristics of the sample regarding anthropometry, body composition, fasting glucose and $\mathrm{BP}$.

The results from the present study indicate that the chosen exercise intensities were significantly distinct, since $\mathrm{VO}_{2}$ at $\mathrm{S} 120$ was higher than S80 (17.6 \pm 0.8 vs. $13.4 \pm 0.3 \mathrm{ml} . \mathrm{kg}$ $\left.1 . \mathrm{min}^{-1}, p<0.05\right)$, and both sessions presented significantly higher mean oxygen uptake when compared to CON $(2.9 \pm 0.1$ ml.kg-1.min $\left.{ }^{-1}, p<0.05\right)$, as shown in Figure 1. Table 2 presents the percentage of maximal oxygen uptake $\left(\mathrm{VO}_{2 \max }\right)$ in which exercise was performed and the rate pressure product as a marker of cardiovascular stress.

Regarding the NO, only the S120 session elicited a significant increase of this variable after exercise (from 7.2 $\mu \mathrm{M}$ to $9.5 \mu \mathrm{M}, p<0.05$ ) (Figure 2).

Post-exercise systolic blood pressure (SBP) decreased significantly $(p<0.05)$ at the $15^{\text {th }}$ and $45^{\text {th }}$ min of S120 when compared to pre-exercise resting values. In addition, only this session elicited a significantly lower SBP values when
Table 1. Main characteristics of the participants $(n=11)$. Data is presented in mean \pm standard deviation.

\begin{tabular}{lc}
\hline & $\begin{array}{c}\text { Individuals with Type-2 } \\
\text { Diabetes }\end{array}$ \\
\hline Age (years) & $62.1 \pm 9.0$ \\
Sex (male/female) & $5 / 6$ \\
Body mass (kg) & $74.8 \pm 12.2$ \\
Height (m) & $1.61 \pm 0.1$ \\
BMI (kg.m ${ }^{-2}$ ) & $28.8 \pm 4.6$ \\
Waist circumference $(\mathrm{cm})$ & $90.3 \pm 10.0$ \\
Fasting glucose $\left(\mathrm{mg} \cdot \mathrm{dL}^{-1}\right)$ & $154.7 \pm 56.8$ \\
SBP at rest $(\mathrm{mmHg})$ & $129.5 \pm 10.1$ \\
$\mathrm{DBP}$ at rest $(\mathrm{mmHg})$ & $73.1 \pm 10.3$ \\
$\mathrm{VO}_{2}$ max $\left(\mathrm{mL} \cdot \mathrm{kg}^{-1} \cdot \mathrm{min}^{-1}\right)$ & $21.1 \pm 4.5$
\end{tabular}

$\mathrm{BMI}=$ body mass index; $\mathrm{SBP}=$ systolic blood pressure; $\mathrm{DBP}=$ diastolic blood pressure; $\mathrm{MBP}=$ mean blood pressure; $\mathrm{VO}_{2} \mathrm{max}=$ maximal oxygen uptake reached during the incremental test.

compared to CON. Diastolic blood pressure (DBP) and mean arterial pressure (MAP) showed no significant changes after exercise during the experimental sessions (Table 3 ).

The correlation between NO and SBP after exercise session at $120 \%$ LT (S120) showed a moderate and significant $(p<0.05)$ correlation coefficient $(r=0.55)$ (Figure 3$)$.

\section{Discussion}

The main findings of the present study were that exercise performed at a higher intensity (120\% of LT) promoted an increase in NO production and, consequently, post-exercise $\mathrm{BP}$ reduction in individuals with T2D. On the other hand,

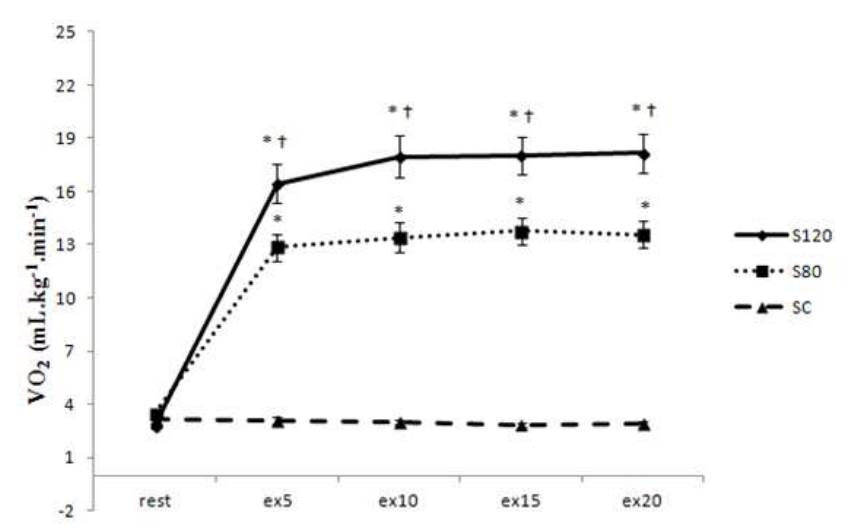

Figure 1. Mean values of oxygen uptake $\left(\mathrm{VO}_{2}\right)$ during exercise in $\mathrm{S} 120, \mathrm{~S} 80$ and $\mathrm{CON}(\mathrm{n}=11)$. ex5-ex20: $5 \mathrm{~min}$ to $20 \mathrm{~min}$ of exercise. $\mathrm{S} 120=$ exercise session at $120 \%$ of lactate threshold; $\mathrm{S} 80=$ exercise session at $80 \%$ of lactate threshold; $\mathrm{CON}=$ control session. ${ }^{*}=$ $p<0.05$ in relation to $\mathrm{CON} ; \dagger=p<0.05$ in relation to $\mathrm{S} 80$. 
Table 2. Results of \% VO2max and rate-pressure product (SBP x HR) during exercise in S120, S80 and CON sessions ( $\mathrm{n}=11)$.

\begin{tabular}{|c|c|c|c|}
\hline & S120 & $\mathbf{S 8 0}$ & $\mathrm{CON}$ \\
\hline$\% \mathrm{VO}_{2} \max$ & $84.7 \pm 6.0^{* \dagger}$ & $54.9 \pm 12.1^{*}$ & $15.5 \pm 2.8$ \\
\hline Rate-pressure product & $17898.0 \pm 2723.1 *$ & $15803.3 \pm 1989.7 *$ & $7632.1 \pm 1184.3$ \\
\hline Blood Lactate (mM) & $5.2 \pm 1.5^{*}$ & $2.8 \pm 0.9$ & $1.3 \pm 0.5$ \\
\hline Blood Glucose (mg.dL $\left.{ }^{-1}\right)$ & $86.7 \pm 11.3^{* \dagger}$ & $103.0 \pm 25.2$ & $114.4 \pm 38.1$ \\
\hline
\end{tabular}

$\mathrm{S} 120=$ exercise session at $120 \%$ of lactate threshold; $\mathrm{S} 80=$ exercise session at $80 \%$ of lactate threshold; $\mathrm{CON}=$ control session; $\mathrm{VO}_{2}$ max $=$ maximal oxygen uptake. $*=p<0.05$ in relation to $\mathrm{CON} ; \uparrow=p<0.05$ in relation to $\mathrm{S} 80$.

Table 3. Between and within comparisons of blood pressure $(\mathrm{mmHg})$ in individuals with type-2 diabetes $(\mathrm{n}=11)$. Data expressed in mean \pm standard deviation.

\begin{tabular}{|c|c|c|c|c|}
\hline & & Rest & rec15 min & rec45 min \\
\hline \multirow[t]{3}{*}{ SBP } & S120 & $126.6 \pm 7.9$ & $118.7 \pm 3.9^{* \dagger}$ & $118.3 \pm 2.9^{*}$ \\
\hline & S80 & $126.2 \pm 14.4$ & $126.1 \pm 7.5$ & $125.1 \pm 11.3$ \\
\hline & $\mathrm{CON}$ & $127.5 \pm 10.1$ & $127.0 \pm 10.6$ & $129.2 \pm 10.9$ \\
\hline \multirow[t]{3}{*}{ DBP } & S120 & $75.6 \pm 6.6$ & $77.1 \pm 4.7$ & $78.6 \pm 7.0$ \\
\hline & S80 & $75.4 \pm 8.8$ & $75.3 \pm 8.5$ & $76.0 \pm 7.9$ \\
\hline & $\mathrm{CON}$ & $71.4 \pm 8.8$ & $75.5 \pm 8.2$ & $73.8 \pm 7.6$ \\
\hline \multirow[t]{3}{*}{ MAP } & S120 & $177.0 \pm 11.4$ & $170.2 \pm 5.3$ & $170.7 \pm 6.2$ \\
\hline & S80 & $184.3 \pm 7.5$ & $176.1 \pm 10.9$ & $175.8 \pm 13.8$ \\
\hline & $\mathrm{CON}$ & $179.9 \pm 8.0$ & $177.3 \pm 13.9$ & $178.4 \pm 12.0$ \\
\hline
\end{tabular}

$\mathrm{SBP}=$ systolic blood pressure; $\mathrm{DBP}=$ diastolic blood pressure; $\mathrm{MAP}=$ mean arterial pressure; rec $15=15^{\text {th }}$ min of post-session recovery; rec $45=45^{\text {th }}$ min of postsession recovery. $*=p<0.05$ to rest in the same session; $\uparrow=p<0.05$ to CON at the same moment.

such findings were not evidenced when exercise was performed at a moderate intensity ( $80 \%$ of LT), since no significant changes were shown in both $\mathrm{NO}$ and post-exercise BP. In this scenario, exercise performed in a higher exercise intensity domain seemed to favor a better post-exercise BP control for individuals with T2D. But the correlation between $\mathrm{NO}$ and PEH was only moderate.

Similar results have been found in a recent study from our laboratory (Santana et al., 2011) in which a significant

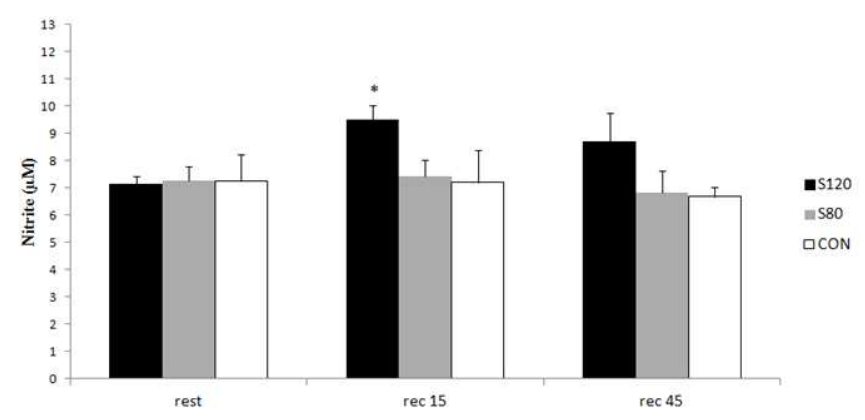

Figure 2. Mean and standard error of nitrite concentration as a marker of NO release at rest, $15^{\text {th }}$ min (rec15) and $45^{\text {th }}$ min of postexercise recovery $(r e c 45)(n=11) . S 120=$ exercise session at $120 \%$ of lactate threshold; S80 = exercise session at $80 \%$ of lactate threshold; $\mathrm{CON}=$ control session. $* p<0.05$ in relation to rest. increase in salivary $\mathrm{NO}$ and greater $\mathrm{PEH}$ were observed after high intensity exercise in elderly women.

In the present study the moderate intensity exercise session was not able to promote an increase in NO production and, therefore, no PEH was presented by our participants. Corroborating to this, Motta et al. (2010), while investigating the effect of T2D on post-exercise of plasma kallikrein activity (a precursor of NO production) and BP after moderate exercise ( $90 \%$ of LT), found a significant

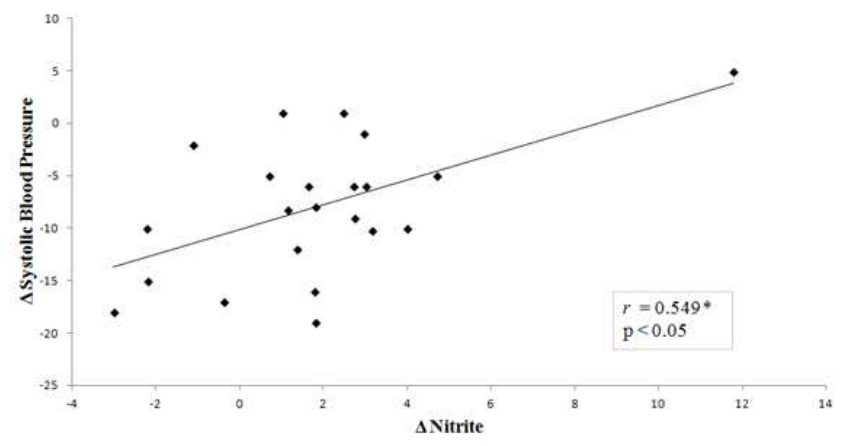

Figure 3. Pearson correlation between Ä systolic blood pressure and $\ddot{A}$ nitrite release at exercise session at $120 \%$ of lactate threshold (S120). 
increase in plasma kallikrein activity and reduction of BP in non-diabetic subjects but not in individuals with T2D. Thus, it is possible that individuals with T2D would be benefitted from exercise bouts performed at higher intensities. Likewise, Lima et al. (2008) found a PEH of greater magnitude and duration in individuals with $\mathrm{T} 2 \mathrm{D}$ after performing exercise at $110 \%$ LT when compared to $90 \%$ LT. However, in these last studies (Motta et al., 2010; Lima et al., 2008), NO was not measured.

In the present study the production of NO seemed to be also dependent of the intensity in which exercise was performed, since only the $\mathrm{S} 120$ resulted in a significant increase in NO concentration associated to a decreased SBP during the post-exercise recovery period. Santana et al. (2011), while investigating the effects of different exercise intensities (maximal exercise vs. 90\% LT intensity) on NO release and post-exercise BP in elderly individuals, also demonstrated a significant NO increase together with $\mathrm{PEH}$ only when the higher intense exercise was performed.

T2D is associated with a decreased activity of the kallikrein-kinin system and elevated oxidative stress that may elicit endothelial dysfunction (Sharma \& Narayanan, 2011; Rodrigo et al., 2007). These processes result in a lower NO release and thus a decreased vasodilation (Asano et al., 2012; Stabler, Katherine, Ham, Jelesoff, \& Allen, 2010). Therefore, these factors could partially explain the impaired ability that individuals with T2D have to present $\mathrm{PEH}$, especially when exercise is performed at lower intensities. However, the effects of performing exercise in different intensities (eg. moderate vs. intense) and type of intervention (i.e. chronic vs. acute exercise) on the endothelial function of individuals with T2D need further investigation.

In spite of this, a moderate correlation between NO release and PEH was observed in the present study, suggesting a possible relationship between exercise intensity, NO release and PEH. Investigations with animal models have suggested that the occurrence of PEH may be mediated by NO (Howard \& DiCarlo, 1992; Patil, DiCarlo \& Collins, 1993). However, the relationship between these factors and mechanisms in humans remain inconclusive. Kingwell, Formosa, Muhlmann, Bradley and McConell (2002) found that the persistent peripheral vasodilation after a single bout of moderateintensity exercise is resistant to nitric oxide synthase inhibition, and it does not appear that PEH would be dependent of increased production of NO in young healthy humans. To our knowledge, however, the present investigation is the first study in humans with T2D analyzing the effects of exercise at different domains of intensity (e.g. below $\mathrm{LT}=$ moderate vs. above $\mathrm{LT}=$ intense) on both $\mathrm{NO}$ and $\mathrm{PEH}$.

In order to benefit from $\mathrm{PEH}$, the T2D individuals with controlled BP and glucose should perform exercise slightly above the anaerobic threshold. These benefits would probably occur due to the higher metabolic and mechanical stress promoted by exercise at such intensity (Teodoro, Natali, Fernandes \& Peluzio, 2010), since PEH is dependent of exercise intensity induced by the increase of the activity of the kallikrein-kinin system, and in consequence, a higher NO release (Pontes et al., 2008). Pharmacological treatments that increase the activity of the kallikrein-kinin system, and thus the production of NO, have shown efficacy in the treatment of individuals with hypertension and T2D (Moreira, Simões, Hiyane, Campbell, \& Simões, 2007). On the other hand, non-pharmacological treatments, such as exercise, have also been characterized as good strategy to improve endothelial function (Rallidis et al., 2009), especially for not presenting collateral effects. Furthermore, Kingwell, Formosa, Muhlmann, Bradley, \& McConell (2002) demonstrated a strong association between glucose uptake and NO production during exercise in T2D.

Even though individuals with type-2 diabetes have impaired NO production at rest (Ghosh, Sherpa, Bhutia, Pal, $\&$ Dahal, 2011), aerobic exercise seems to acutely increase the production of this metabolite in T2D population, especially in more intense exercise sessions. Additionally, studies have also associated a higher production of NO in T2D individuals with an increase in glucose uptake (Kingwell, Formosa, Muhlmann, Bradley, \& McConell, 2002; Mcconell \& Kingwell, 2006), both effects being extremely relevant for T2D.

Moreover, the $120 \%$ LT session was considered safe for our participants, once the main cardiovascular, metabolic and ventilatory responses did not increase over proportionally during exercise session, remaining within recommended values (American College of Sports Medicine, 1998). On the other hand, we suggest caution on prescribing aerobic exercise above LT, particularly in sessions lasting up to 20 minutes for individuals with low fitness and clinical limitations to exercise. If applicable, prescription of high intensity exercise should be done on an individual basis (e.g. severity of diabetes should be considered) and after appropriate medical screening. Such above LT prescriptions should be limited to those patients without cardiovascular and metabolic complications.

One possible limitation of the present study was the absence of a control group of individuals without diabetes. However, previous studies have already presented that individuals with T2D have lower production of NO, lower vasodilation, and, consequently, higher $\mathrm{BP}$ values at rest when compared to their non-diabetic pairs (Mather, Lteif, Steinberg, \& Baron, 2004). Moreover, the intensities of the session were different (120\% LL and 80\% LL) but the exercise duration was the same (20 minutes) for both sessions. Thus, the training load was higher during the intense exercise session (S120). Therefore, it is important that future studies comparing exercise performed in the same workload but in different intensities in order to evaluate the differences related to intensity and training load.

\section{Conclusion}

Based on the present findings, we conclude that NO production and the occurrence of $\mathrm{PEH}$ seems to be 
dependent of exercise intensity, since only exercise performed above the LT significantly increased the production of $\mathrm{NO}$ and promoted $\mathrm{PEH}$ in individuals with T2D. However, the prescription of high intensity exercise must be done with caution and on an individual basis. Therefore, future research on this topic should focus on the safety of exercise protocols above the LT, as well as the chronic effects of exercise on the production of $\mathrm{NO}$ and $\mathrm{PEH}$ in individuals with diabetes.

\section{References}

American College of Sports Medicine. (1998). Exercise for patients with coronary artery disease. Medicine and Science in Sports and Exercise, 5, 1-5.

Asano, R. Y., Sales, M. M., Coelho, J. M., Moraes, J. F. V. N., Pereira, L. A., Campbell, C. S. G., \& Simões, H. G. (2012). Exercise, nitric oxide, and endothelial dysfunction: a brief review. Journal of Exercise Physiology Online, 15, 76-86.

Bahr, R., \& Sejersted, O.M. (1991). Effect of intensity of exercise on excess postexercise $\mathrm{O}_{2}$ consumption. Metabolism: Clinical and Experimental, 40, 836-841.

Chobanian, A. V., Bakris, G. L., Black, H. R., Cushman, W. C., Green, L. A., Izzo J. L. Jr., ... National High Blood Pressure Education Program Coordinating Committee. (2003). The National High Blood Pressure Education Program Coordinating Committee: the seventh report of the Joint National Committee on Prevention, Detection, Evaluation, and Treatment of High Blood Pressure: the JNC 7 report. JAMA: The Journal of the American Medical Association, 289, 2560-2572.

Colberg, S. R., Sigal, R. J., Fernhall, B., Regensteiner, J. G., Blissmer, B. J., Rubin, R. R., ... American Diabetes Association. (2010). Exercise and type 2 diabetes: the American College of Sports Medicine and the American Diabetes Association: joint position statement. Diabetes Care, 33, 147167.

Denadai, B. S., \& Caputo, F. (2003). Efeitos do treinamento sobre a cinética do consumo de oxigênio durante o exercício realizado nos diferentes domínios de intensidade de esforço. Motriz, 9, S1-S7.

Ghosh, A., Sherpa, M. L., Bhutia, Y., Pal, R., \& Dahal, S. (2011). Serum nitric oxide status in patients with type 2 diabetes mellitus in Sikkin. International Journal of Applied and Basic Medical Research, 1, 31-35.

Halliwill, J. R., Minson, C. T., \& Joyner, M. J. (2000). Effect of systemic nitric oxide synthase inhibition on postexercise hypotension in humans. Journal of Applied Physiology, 89, 1830-1836.

Howard, M. G. \& DiCarlo, S. E. (1992). Reduced vascular responsiveness after a single bout of dynamic exercise in the conscious rabbit. Journal of Applied Physiology, 73, 2662-2667.

Howley, E., Bassett, D. J., \& Welch, H. (1995). Criteria for maximal oxygen uptake: review and commentary. Medicine and Science in Sports and Exercise, 27, 1292-1301.

Hu, F. B., Leitzmann, M. F., Stampfer, M. J., Colditz, G. A., Willett, W. C., \& Rimm, E. B. (2001). Physical activity and television watching in relation to risk for type 2 diabetes mellitus in men. Archives of Internal Medicine, 161, 15421548.

Kingwell, B. A., Formosa, M., Muhlmann, M., Bradley, S. J., \& McConell, G. K. (2002). Nitric oxide synthase inhibition reduces glucose uptake during exercise in individuals with type
2 diabetes more than in control subjects. Diabetes, 51, 25722580.

Lima, L. C., Assis, G. V., Hiyane, W., Almeida, W. S., Arsa, G., Baldissera, V., ... Simões, H. G. (2008). Hypotensive effects of exercise performed around anaerobic threshold in type 2 diabetic patients. Diabetes Research and Clinical Practice, 81, 216-222.

Mather, K. J., Lteif, A., Steinberg, H. O., \& Baron, A. D. (2004). Interactions between endothelin and nitric oxide in the regulation of vascular tone in obesity and diabetes. Diabetes, 53, 2060-2066.

Mcconell, G. K., \& Kingwell, B. A. (2006). Does nitric oxide regulate skeletal muscle glucose uptake during exercise? Exercise and Sport Sciences Reviews, 34, 36-41.

Miche, E., Herrmann, G., Nowak, M., Wirtz, U., Tietz, M., Hürst, M., ... Radzewitz, A. (2006). Effect of an exercise training program on endothelial dysfunction in diabetic and non-diabetic patients with severe chronic heart failure. Clinical Research in Cardiology, 95, 117-124.

Morais, P. K., Campbell, C. S. G., Sales, M. M., Motta, D. F., Moreira, S. R., Cunha, V. N. C., ... Simões, H. G. (2011). Acute resistance exercise is more effective than aerobic exercise for $24 \mathrm{~h}$ blood pressure control in type 2 diabetics. Diabetes \& Metabolism, 37, 112-117.

Moreira, S. R., Simões, G. C., Hiyane, W. C, Campbell, C. S. G., \& Simões, H. G. (2007). Identificação do limiar anaeróbio em indivíduos com diabetes tipo-2 sedentários e fisicamente ativos. Revista Brasileira de Fisioterapia, 11, 289-296.

Motta, D. F., Lima, L. C. J., Arsa, G., Russo, P. S., Sales, M. M., Moreira, S. R., ... Campbell, C. S. G. (2010). Influence of type 2 diabetes on kallikrein activity after physical exercise and its relationship with post exercise hypotension. Diabetes \& Metabolism, 36, 363-368.

Patil, R. D., DiCarlo, S. E. \& Collins, H. L. (1993). Acute exercise enhances nitric oxide modulation of vascular response to phenylephrine. American journal of physiology. Heart and circulatory physiology, 265, 184-188.

Pescatello, L. S., Fargo, A. E., Leach, C. N. Jr, \& Scherzer H. H. (1991). Short-term effect of dynamic exercise on arterial blood pressure. Circulation, 83, 1557-1561.

Pontes, F. L. Jr, Bacurau, R. F., Moraes, M. R., Navarro, F., Casarini, D. E., Pesquero, J. L., ... Piçarro, I. C. (2008). Kallikrein kinin system activation in postexercise hypotension in water running of hypertensive volunteers. International Immunopharmacology, 8, 261-266.

Poole, D. C., \& Richardson, R. S. (1997). Determinants of oxygen uptake. Implications for exercise testing. Sports Medicine, 24, 308-320.

Rallidis, L. S., Lekakis, J., Kolomvotsou, A., Zampelas, A., Vamvakou, G., Efstathiou, S., ... Kremastinos, D. T. (2009). Close adherence to a Mediterranean diet improves endothelial function in subjects with abdominal obesity. The American Journal of Clinical Nutrition, 90, 263-268.

Resnick, H. \& Howard, B. (2002). Diabetes and cardiovascular disease. Annual Review of Medicine, 53, 245-267.

Rodrigo, R., Prat, H., Passalacqua, W., Araya, J., Guichard, C., \& Bächler, J. P. (2007). Relationship between oxidative stress and essential hypertension. Hypertension Research, 30, 11591167.

Sales, M. M., Campbell, C. S., Morais, P. K., Ernesto, C., SoaresCaldeira, L. F., Russo, P., ... Simões, H. G. (2011). Noninvasive method to estimate anaerobic threshold in individuals with type 2 diabetes. Diabetology \& Metabolic Syndrome, 3, 1-8.

Sales, M. M., Russo, P., Moreira, S. R., Santana, H. A. P., Moraes, 
J. F. V. N., Asano, R. Y., ... Campbell, C. S. G. (2012). Resistance exercise elicits acute blood pressure reduction in type 2 diabetics. Journal of Exercise Physiology online, 15, 98-109.

Santana, H. A., Moreira, S. R., Neto, W. B., Silva, C. B., Sales, M. M., Oliveira, V. N., ... Simões, H. G. (2011). The higher exercise intensity and the presence of allele I of ACE gene elicit a higher post-exercise blood pressure reduction and nitric oxide release in elderly women: an experimental study. BMC Cardiovascular Disorders, 11, 1-8.

Sharma, J. N. \& Narayanan, P. (2011). Hypertension and diabetes: contribution of the kallikrein-kinin system. Journal of Diabetes \& Metabolism, 8, 1-5.

Simões, H. G., Denadai, B. S., Baldissera, V., Campbell, C. S. G., \& Hill, D. W. (2005). Relationships and significance of lactate minimum, critical velocity, heart rate, deflection and $3000 \mathrm{~m}$ track-tests for running. The Journal of Sports Medicine and Physical Fitness, 45, 441-451.

Simões, H. G., Hiyane, W. C., Benford, R. E., Madrid, B., Prada, F. A., Moreira, S. R., ... Campbell, C. S. (2010). Lactate threshold prediction by blood glucose and rating of perceived exertion in people with type 2 diabetes. Perceptual and Motor Skills, 111, 365-378.

Simões, H. G., Moreira, S. R., Moffatt, R. J., \& Campbell, C. S. G. (2010). Métodos para identificar o limiar anaeróbio em indivíduos com diabete tipo 2 e em indivíduos não-diabéticos. Arquivos Brasileiros de Cardiologia, 94, 71-78.

Stabler, T., Katherine, A. K., Ham, K., Jelesoff, N., \& Allen, J. (2010). Potential mechanisms for reduced delivery of nitric oxide to peripheral tissues in diabetes mellitus. Annals of The New York Academy of Sciences, 1206, 101-106.

Teodoro, B. G., Natali, A. J., Fernandes, S. A. T., \& Peluzio, M. C. G. (2010). The aerobic physical exercise intensity influence on the atherosclerotic. Revista Brasileira de Medicina do Esporte, 16, 382-387.

Tsikas, D. (2007). Analysis of nitrite and nitrate in biological fluids by assays based on the Griess reaction: appraisal of the Griess reaction in the L-arginine/nitric oxide area of research. Journal of chromatography. B, Analytical technologies in the biomedical and life sciences, 851, 51-70.

Wild, S., Roglic, G., Green, A., Sicree, R., \& King, H. (2004). Global prevalence of diabetes: estimates for the year 2000 and projections for 2030. Diabetes Care, 27, 1047-1053.

\section{Authors' note}

Ricardo Yukio Asano is affiliated with the Catholic University of Brasília, Brasília, Distrito Federal, Brazil and the Municipal foundation of higher education in Bragança Paulista - Brazil.

Rodrigo Alberto Vieira Browne is affiliated with the Federal University of Rio Grande do Norte, Natal, Rio Grande do Norte, Brazil;

Rafael da Costa Sotero, Marcelo Magalhães Sales, Carmen Sílvia Grubert Campbell1 and Herbert Gustavo Simões are affiliated with the Catholic University of Brasília, Brasília, Distrito Federal, Brazil;

José Fernando Vila Nova de Moraes is affiliated with the Catholic University of Brasília, Brasília, Distrito Federal, Brazil and the Federal University of Vale do São Francisco, Petrolina, Pernambuco, Brazil.

\section{Correspondence}

Ricardo Yukio Asano and Herbert G Simões

Programa de Pós-Graduação Stricto Sensu em Educação Física da Universidade Católica de Brasília

EPTC, QS 07, LT 1, BL G, Sala 116.

Águas Claras, Brasília 72.022-900 DF, Brasil

Phone: +55 (11) 97011-5500

Email: ricardokiu@ig.com.br; hgsimoes@gmail.com

\section{Funding}

This work was supported by the Conselho Nacional de Desenvolvimento Científico e Tecnológico - CNPq/Universal [grant number 473598/2010-8] and Coordenação de Aperfeiçoamento de pessoal de nível superior (CAPES/PROCAD-NF).

\section{Acknowledgements}

The authors would like to thank to the Coordenação de Aperfeiçoamento de Pessoal de Nível Superior (CAPES) and Conselho Nacional de Desenvolvimento Científico e Tecnológico (CNPq) for the finantial support to the study, as well as for the Master's scholarship grants (CAPES), PhD (CAPES and CNPq), and for an independent research grant $(\mathrm{CNPq})$.

This study was presented at the $8^{\text {th }}$ International Congress of Physical Education and Human Movement and $14^{\text {th }}$ Symposium Paulista Physical Education.

Declaration of Conflicting Interests: The authors declared no conflicts of interest exist with respect to the research, authorship, and/or publication of this article.

Manuscript received on March 30, 2013

Manuscript accepted on May 17, 2013 